\title{
Does infrastructure spending lead to price effects in the property market? Evidence from major cities across India
}

Article

Accepted Version

Deng, X., Nanda, A. and Ong, S. E. (2019) Does infrastructure spending lead to price effects in the property market?

Evidence from major cities across India. Regional Studies, 53 (12). pp. 1747-1760. ISSN 1360-0591 doi:

https://doi.org/10.1080/00343404.2019.1619925 Available at https://centaur.reading.ac.uk/83708/

It is advisable to refer to the publisher's version if you intend to cite from the work. See Guidance on citing.

To link to this article DOI: http://dx.doi.org/10.1080/00343404.2019.1619925

Publisher: Routledge

All outputs in CentAUR are protected by Intellectual Property Rights law, including copyright law. Copyright and IPR is retained by the creators or other copyright holders. Terms and conditions for use of this material are defined in the End User Agreement.

www.reading.ac.uk/centaur 
Central Archive at the University of Reading

Reading's research outputs online 


\title{
Does Infrastructure Spending Lead to Price Effects in the Property Market? Evidence from Major Cities across India
}

\author{
Xiaoying $\mathrm{DENG}^{1}$ \\ Anupam NANDA ${ }^{2}$ \\ Seow Eng $\mathrm{ONG}^{3}$
}

\begin{abstract}
A recent boost in spending on the public infrastructure across India raises the question: how does the property sector react to massive infrastructure construction? The answer have significant policy relevance. This paper uses panel data across seven major Indian cities, spanning seven years from 2008 to 2014, to ascertain the short-run and long-run impacts of infrastructure attributes on property values and rents. The study finds that increases in the percentage of public infrastructure spending lead to a positive effect on the property capitalisation rate in India, but have a negative impact on the rental market in the short term.
\end{abstract}

Keywords: Infrastructure Spending, Rental Price, Cap Rate

\footnotetext{
${ }^{1}$ Corresponding Author, School of Public Economics and Administration, Shanghai University of Finance and Economics, 777 Guoding Road,Shanghai, China,200433,Email:_eng.xiaoying@mail.sbufe.edu.cn.deng.xiaoying@mail.shufe.edu.cn.

${ }^{2}$ Henley Business School, University of Reading, Whiteknights, Reading RG6 6UD, UK. E-mail: a.nanda@,reading.ac.uk.

${ }_{3}^{3}$ Department of Real Estate, National University of Singapore, 4 Architecture Drive, Singapore, 117566. Email: seong@,nus.edu.sg.
} 


\section{Introduction}

Almost $70 \%$ of the world population is going to live in urban areas by 2050 , according to a recent UN (2008) report on world population prospects. For the past decade, India's infrastructure industry has experienced steady growth. As reported by the Economist (15/12/2012), between 2007 and 2012, the private sector invested as much as $\$ 225$ billion in infrastructure in India during $2007-12^{4}$. This is equivalent to almost $12 \%$ of GDP in 2012. According to a Government of India report, urbanisation is expected to intensify with the urban population reaching approximately 600 million by 2031 and 850 million by $2051^{5}$. This rapid urbanisation in India would bring about huge demand for houses, as well as high-quality public services for the households. A major, fast-growing economy such as India needs to provide ample public infrastructure due to mounting demands from a growing urban population. This has led to massive spending on improving infrastructure networks and creating new ones. Infrastructure spending is also a popular fiscal stimulus. The idea stems from the economic principle of the demand 'multiplier' effect, i.e. economic development can be kick-started or boosted through job creation in the economy. Infrastructure spending creates room for future development and other investments.

One of the key sectors for development and further investment due to an infrastructure boost is the property sector. The land being opened up for development can lead to significant increases in new construction and thus, the supply of properties. Moreover, both residential and non-residential property sector developments may be correlated, as the needs for both of these types of properties are often interlinked due to simultaneity in job and residence location choices. Public capital may also lead to growth in private capital spending, by removing bottlenecks and thus raising economic productivity. Regions and countries do vary in their institutional backgrounds, resulting in a varying receptiveness for public spending. Regional heterogeneity in institutional constraints may influence the channels through which the effect of infrastructure spending leads to economic development. At the regional level, the possibility of leakage effects can substantially dampen potential growth prospects, where a sizeable portion of the benefits of infrastructure improvement can be reaped by the neighbouring regions. This is especially

\footnotetext{
${ }^{4}$ See https://www.economist.com/finance-and-economics/2012/12/15/rippp

${ }^{5}$ See https://unfccc.int/sites/default/files/resource/INDIA\%20SECOND\%20BUR\%20High\%20Res.pdf
} 
true in a country such as India, which has a large number of contiguous and heterogeneous states with a diverse range of institutional factors.

A number of studies have documented the role of infrastructure investments as key drivers for a country's economic growth (see Prud'homme, 2005 for a review). Developing infrastructure enhances a region's comparative advantage through the improvement of productivity efficiency, transportation and the urban amenities (OECD, 2008). Developed countries focus on replacement and upgrading of their aging infrastructures, while developing countries build new infrastructure to fuel economic growth.

As the current Indian government is planning for massive infrastructure investment (e.g. high-speed railways and highways), a pertinent question is: how will the property sector react to massive infrastructure construction? We use panel data across major Indian cities spanning seven years from 2008 to 2014, to ascertain the impact of infrastructure attributes on property values. Local and state fixed effects are included to control for unobserved heterogeneity. We document that increases in the percentage of public infrastructure spending have a positive effect on the capitalisation rate in India, but a negative impact on the rental market. The effect of changes in the public infrastructure is examined over different construction periods to focus on the long-run effect, which is more likely to be capitalised into the cap rate. The better access to the infrastructure tends to increase the supply of real estate relative to demand in the property sector, resulting in higher market cap rates over the long run.

Contributions of this paper are manifold. First, our paper complements a rich body of literature analysing the relationships between infrastructure investment and economic growth in both developing and developed countries. Second, our paper documents that the property sector benefits from better access to infrastructure; the wealth effect of which serves as a channel to overall economic growth. Thirdly, our investigation of the propertysector consequences of city-based investments contributes to recent literature on gentrification due to rapid urbanisation with a multitude of inflationary impacts on prices and rents. The increased labour mobility, along with strong income growth, raises the demand for urban amenities, contributing to land rent differentials. As infrastructure investment is of considerable relevance in improving urban amenities, it is also likely to explain the current land rent differentials and real estate price dynamics in the property sector. However, there are only a few studies that directly examine the wealth effect of infrastructure investment on the property sector. Our research fills the gap. The findings 
also have significant policy relevance in terms of curbing property market fluctuation; identifying pockets of development and local urban planning; issues and mechanisms of land value capture; and the formation of an agglomeration economy etc.

The paper is organised as follows: Section 2 reviews the literature on infrastructure investment. Section 3 develops our hypotheses. Section 4 describes the empirical design and data sources. Section 5 presents the main findings and robustness checks. Section 6 concludes the paper with a brief discussion on policy implications.

\section{Literature Review}

The relationship between infrastructure investment and the property sector revolves around the fact that the 'network' infrastructures, such as roads and airports, open up the land for future development. As Ball and Nanda (2014) note that the property sector perspective is based on the possibility that economic activities across various sectors are accommodated in buildings and transmitted through the property sector. Therefore, expanded local business activity stimulated by infrastructure investment is likely to lead to more commercial building to accommodate it, especially in service-dominated economies. Related to this, the housing sector is also stimulated due to increased labour market activity and changes in travel-to-work patterns. Interestingly, Cohen and Morrison (2007) present evidence of significant positive effects of public infrastructure on US property prices, and the size of the effect depends on distance from the investment, with the effect being less for more distant properties. The results show that rental growth was similar in regeneration locations compared to the prime market. However, they find a major cap rate shift for property in regeneration areas in the short to medium term. In a recent paper, Cohen and Brown (2017) estimate the net capitalisation effect for each individual commercial property price resulting from expected improved urban centre access using a rail rapid transit line announcement in Vancouver, BC, Canada. Haughwout (1997) presents evidence that a $10 \%$ increase in central city infrastructure can lead to $0.61 \%$ appreciation in suburban house values. Without considering the tax effects, it means, the cost of a $10 \%$ increase in infrastructure would be approximately $\$ 1$ billion, while the increase in housing value would be approximately $\$ 3$ billion. Boarnet (1997) finds a 'leeching' effect of nearby infrastructure, where the most productive resources are drawn away from a region when a nearby region enhances its infrastructure. Kelejian and Robinson (1997) find mixed effects of public 
infrastructure on productivity; depending on the econometric specifications, the results can vary widely. Holtz-Eakin and Schwartz (1995) report a similar lack of statistically significant evidence. Gibbons and Machin (2008) also argue that it is not possible to draw a clear conclusion on the impact of transport improvements on house prices due to differences in the context and local area dynamics.

A rich body of literature explores the causal relationship between infrastructure development and economic growth (Ahlfeldt, 2011; Atack et al., 2010; Banerjee et al., 2012; Baum-Snow, 2007; Baum-Snow et al., 2012; Datta, 2012; Faber, 2014; Ghani et al., 2012). The wealth effect of access to infrastructure is documented to transfer to the economy via agglomeration. Developing infrastructure enhances a region's comparative advantage (Newell and Peng, 2008) through the improvement of productivity efficiency, transportation and urban amenities.

The question essentially revolves around the size, direction and nature of the impacts resulting from such effects. Using aggregate time series analysis in a couple of seminal studies, Aschauer (1989) concludes that public building investment has a statistically significant impact on economic growth. A number of studies have supported Aschauer's findings (for example, Berndt and Hansson, 1992, using Swedish data; Canning and Fay, 1993, using a panel data analysis of 96 countries; and Lynde and Richmond, 1991, using US data; see also Gramlich, 1994, and Munnell, 1992, for a survey of the literature.).

A number of studies focused on the effect of infrastructure on productivity. Infrastructure investment can reduce (or remove) mobility constraints of factors of production and, thereby, it can result in a positive effect on the productivity of labour and capital. Using Mexican manufacturing industries as the case study, Shah (1992) provides such evidence of the economic significance of public infrastructure investment on private sector profitability. Other studies have also confirmed such effects using data from different countries (Nadiri and Mamuneas, 1994, for US manufacturing industries; Seitz, 1994, and Seitz and Licht, 1995, for the West German manufacturing industries) However, quite a few studies have also found no statistical significance for such relationships (Tatom, 1991; Evans and Karras, 1993). Quite clearly, no consensus appears to have emerged, as yet, in the literature using aggregate national data.

The regional analysis suffers from a range of biases due to the presence of significant unobserved heterogeneity at various geographic levels within an array of effects, such as 
network and spillover/leakage effects, that are hard to quantify. A group of studies (see Pereira and Andraz, 2008 for a list of the relevant studies) used regional- or state-level panel data to understand these relationships. Using data from 28 US metropolitan areas, Duffy-Deno and Eberts (1991) find positive and statistically significant effects of public infrastructure on regional economic development. The choice of proxy is an important consideration in answering this question, as the problem of endogenous feedback may be significant. Similarly, other studies find comparable evidences (Garcia-Milà and McGuire, 1992; Munnell and Cook, 1990). However, many studies have also presented contradicting or non-supporting evidences of a positive relation (e.g. Pereira and Andraz, 2008; Evans and Karras, 1993; Garcia-Milà et al., 1996; Holtz-Eakin, 1994).

The possibility of spillover effects or leakage from investment in one region to other regions is an important aspect of the regional analysis. Pereira and Andraz (2004, 2006) present the possibility of significant regional spillover effects using US and Portuguese data, respectively. Studying Spanish regions, Pereira and Roca-Sagales (2002) also find considerable spillover effects. Haughwout (1998) provides a model and presents a quantitative example showing that increases in public goods may not always result in higher equilibrium output at the regional level. However, the extent of the effects may crucially depend on the infrastructure endowment of the regions.

Shirley and Winston (2004) show that the rate of return from highway infrastructure spending decreased over time in the US - from about $17-25 \%$ in the 1970 s to $4.9-7 \%$ in the 1980s and to about 1\% in the 1990s. As McDonald and McMillen (2010) comment, the reduction could be attributed to the increasing stock of infrastructure, i.e. diminishing marginal returns. Therefore, the positive feedback effect of infrastructure spending may not be guaranteed across regions. However, in a developing country, the positive effect can be achieved relatively easily, as the endowment level is low and incremental impacts are more pronounced.

A recent strand of literature also focuses on urban gentrification due to the access to infrastructure. Kahn (2007) documents that newly opened 'walk and ride' subway stops for fast new subways contribute to an increase in local home prices in major US cities, such as Boston and Washington DC. Guerrieri et al. (2010) report evidence of spatial spillovers, in which exogenous increases in income in one community lead to an increase in real estate prices in adjacent communities. Cohen and Morrison (2004) test for spatial spillover and apply a cost-function model to 1982-1996 state-level US manufacturing data, in order to 
untangle the private cost-saving effects of inter- and intrastate public infrastructure investment. Morrison and Schwartz (1996), using a cost-based methodology, find that, in the short run, public capital expenditures provide cost-saving benefits that exceed the associated investment costs due to substitutability between public capital and private inputs. Kahn et al. (2010) also document the gentrification in Los Angeles communities.

\section{Hypotheses}

The above literature review leads to several testable hypotheses. As mentioned, our focus is on the property sector, which acts as the reflector of economic activities. As evident from the following diagram, a significant extent of the economic benefits from infrastructure investment will be transmitted through the property sector.

\section{[Insert Figure 1]}

Two possible transmission channels for the impacts of infrastructure spending on the property market are: (i) sectoral spillover effects caused by stimulating investments in other economic sectors, creating demand for space and (ii) spatial spillover effects, caused by influencing property sub-markets and urban economic geography. Dynamic effects through both channels would be reflected by key property market indicators based on the following hypotheses:

A. Supply shifter: Infrastructure spending would open up developable land, leading to various property development activities and, thus, increased supply. An increase in supply, ceteris paribus, would exert downward pressure on price variables - the rent and sales value of properties.

B. Demand shifter: Infrastructure spending would act as booster for various employment generating sectors. Increased employment opportunities (and recruitment intentions) and business expansion would lead to increased demand for space, leading to upward pressure on price variables - the rent and sales value of properties. Moreover, infrastructure spending may also boost investment sentiment with potential implications for the cap rate.

C. Net effect: the above effects may work in tandem and, therefore, the net effect in a local area may depend on infrastructure endowment and current levels of prices. 
In a developing country, such as India, the demand shifting effect would probably dominate due to low levels of price variables and rapid business expansions. In the seven Indian major cities in this study have been experiencing rapid business expansions, including the emergence of employment generating sub-sectors.

\section{Empirical Design and Data Sources}

The dataset used in this paper consists of both data on infrastructure investment and property transactions. We focus on the following Indian cities: Bengaluru, Chennai, Hyderabad, Kolkata, Mumbai, Delhi and Pune. The seven cities are among the 'Big Eight', with populations exceeding 5 million people each and an urgent need for generating agglomeration economies via massive urban infrastructure. The sample used is from 2008 to 2014. We hand-collected the infrastructure data on highway and bridge construction from the Secretariat for India's Planning Commission (see www.infrastructure.gov.in). We then constructed a dataset including property transaction information from the cities with access to infrastructure. Macro data are retrieved from DataStream.

Using a simple theoretical framework around demand multiplier effects, we examined testable hypotheses and used both primary and secondary information in our data analysis. We modelled two key property sector performance indicators: rental growth and cap rate. Nanda and Tiwari (2013) estimate a single-step adjustment model with lagged cap rate, the ratio of real rent index for a given location in a given quarter to its historical average, the real Treasury bond yield, the spread between corporate bond index and Treasury bond yield and the liquidity measure as ratio of total net borrowing and lending to nominal GDP.

We extend the above-mentioned modelling approach, by incorporating fundamental drivers of the local property market and examining various property market indicators including the cap rate. Local area employment is a significant demand shifter for commercial space, as well as residential development. However, as discussed before, the emergence of developable land may be triggered by improved infrastructure. Therefore, infrastructure spending may act as a supply shifter across the property markets. The basic model of interaction of demand and supply shifters can be written as Equation 1:

$$
\ln \left(k_{i t}\right)=\alpha_{0}+\beta_{1} X_{i t}+\beta_{2} Z_{i t}+\varepsilon_{i t}
$$

Where, $k_{i t}$ is a property market indicator such as rental growth, capital value growth, vacancy rate, net absorption, and cap rate. $\mathrm{X}_{\mathrm{it}}$ is a vector of local area (i) attributes, such as 
employment and rent ratio at time $t . Z_{i t}$ is a vector of macroeconomic variables such as risk spread, liquidity, real GDP growth, stock market performance etc. The literature has also included lagged dependent variable to help identify the robust effects, as shown in Equation 2:

$$
\ln \left(k_{i t}\right)=\alpha_{0}+\beta_{1} \ln \left(k_{i t-1}\right)+\beta_{2} X_{i t}+\beta_{3} Z_{i t}+\varepsilon_{i t}
$$

A key variable in our study is infrastructure spending $\left(I_{i t}\right)$, which can now be incorporated as shown in Equation 3:

$$
\ln \left(k_{i t}\right)=\alpha_{0}+\beta_{1} \ln \left(k_{i t-1}\right)+\beta_{2} X_{i t}++\beta_{3} Z_{i t}+\beta_{4} I_{i t}+\varepsilon_{i t}
$$

$I_{i t}$ may be specified in level (depending on availability of data) or as an indicator variable. Unobserved heterogeneity may be modelled as fixed effects, after conducting the Heckman's specification test. However, we envisage that fixed effect modelling may be more appropriate than random effect modelling due to the presence of a small number of large cross-sections. We employ a fixed effect panel data method to estimate the model. The advantage of this method is that it allows us to use both time series and cross-sectional variations in the data, which increases the efficiency of the Ordinary Least Squares (OLS) estimates. A potential bias in estimating equation (3) is the possibility of a correlation between unobserved heterogeneity at the local area level and the observables, which would violate standard assumptions of OLS estimation. Therefore, the disturbance term in equation (3) is specified as a two-way error component model with area-specific fixed effects and time-specific effects. In this fixed effect specification, heterogeneity is assumed to be constant over time and correlated with independent variables.

To analyse the impact of infrastructure investment on the property market, we regress the rental price recorded on each lease transaction on the infrastructure attributes in the panel, as shown in Equation 4:

$$
\ln \left(\text { Rental }_{j i t}\right)=\alpha_{i}+\beta_{1} \text { Infras Attributes }_{i t}+\text { rontrols }_{i t-1}+\text { Year }_{t}+\text { City }_{i}+\varepsilon_{i t}
$$

Rental $_{j i t}$ is the rental price recorded on the lease transaction $j$ of city $i$ in time $t . \alpha_{\mathrm{i}}$ is region fixed effect. Infras Attributes take Infras_dummy, In(Infras_length), In(Infras_spending), In(Infras_lengthtotal), In(Infras_spendingtotal) respectively. 
We measure Infras_dummy, i.e. the city's access to infrastructure, using the following variables. We denote Infras_dummy equal to 1, if the infrastructure investment is observed for the given city at time $t$. Infras_length measures the length of highways under construction for the given city at time $t$. Infras_spending measures the estimated spending on highways under construction for the given city at time $t$. Infras_lengthtotal measures the total length of highways under construction and completed for India at time $t$. Infras_spendingtotal measures the total estimated spending on highways under construction and completed for India at time $t$.

Control variables include both property attributes and macro variables. Area is the size of property on file. Macro control variables include GDP, Stock, CPI, and Consumption. GDP is the log difference of gross domestic product (GDP), Interest Rate is the three-month deposit rate, CPI is the quarterly average of monthly Consumer Price Index (CPI), and Consumption is the log difference of private consumption. We use the log difference of the stock index as the proxy for growth in the traded stock (Stock).

We then analyse the impact of infrastructure investment on the cap rate based on the traditional cap rate model in the property sector, see Equation 6. It is also notable that the body of academic work on the determinants of cap rates is largely silent on the effect of capital flows. Chervachidze and Wheaton (2013) focus on availability of debt (debt flow) as a driver of capitalisation, finding that changes in debt availability at the national level have significant effects on cap rates.

$$
\begin{aligned}
& \ln \left(\text { Cap Rate }_{j i t}\right)=\alpha_{i}+\beta_{1} \text { Infras Attributes }_{i t}+\beta_{2} \text { Risk Premium }+
\end{aligned}
$$

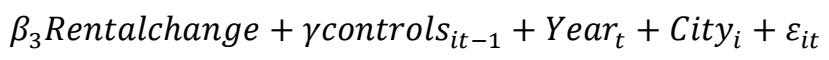

We measure Cap Rate for each leased property on file as the rental price over the selling price of the comparable property adjusted by the risk-free rate, measured as the treasury rate. $\alpha_{\mathrm{i}}$ is region fixed effect. Risk Premium is the market factor, calculated as the difference of stock market return over risk free rate. Rentalchange is calculated as the deviation from the long-run average rental price for each city. Infras Attributes are Infras_dummy, In(Infras_length), In(Infras_spending), In(Infras_lengthtotal), and In(Infras_spendingtotal). Control variables include both property attributes and macro variables as described in Table 1.

Finally, our interests on the benefit of infrastructure spending are not just on the impact on rental prices, which tends to be relatively short term, but also in the subsequent change 
in access to infrastructure. To analyse the long-term impact, we examine the impact of infrastructure investment on both rental prices and cap rate over the subsequent period in the Equation 6:

$$
\begin{aligned}
& \text { PropertyIndicator }_{j i, t+n}=\alpha_{i}+\beta_{1} \text { Infras Attributes }_{i t}+\gamma \text { controls }_{i t-1}+\text { Year }_{t}+ \\
& \text { City }_{i}+\varepsilon_{i t}
\end{aligned}
$$

\section{Empirical Results}

\subsection{Main Results}

This section reports the empirical evidence on how infrastructure investment affects the property market. Table 1 shows the summary statistics for all the variables used in the empirical analysis. The mean of Rental Price is INR 64.99 per sq ft, with the standard deviation 51.56. Massive infrastructure investments are observed in the sample period, with the average Infras_length being $57.85 \mathrm{~km}$ on highway and bridge constructions at the city level annually. The average spending on infrastructure investments amounts to INR 193.39 crore annually. The standard deviation of the Risk Premium is 1.95\% with a mean of 3.27 , indicating risk premium is significant.

[Insert Table 1 here]

Table 2 reports the results of how infrastructure investment affects rental prices. Column (1) reports the results with the simplest specification of only infrastructure attributes, and they explain about $24.2 \%$ of rental prices. The length of highway under construction, as a proxy for the penetration of the infrastructure investment at the city level, is significant and is negatively associated with the rental price. For each 1\% expansion in the city's highway, the rental price is further decreased by $0.023 \%$. Column (2) reports the results with control variables. Infrastructure development on the city level decreases the rental prices, while the overall infrastructure on the country level is likely to have a positive impact on the rental prices. In columns (3) and (4), we include the interaction term that is proxy for the total project announced at the time $t$ for the given city in the regression, where the interaction terms remain significant and negative. Columns (5) to (8) further report the results on how the infrastructure spending affects the rental prices and the results are broadly similar. Column (5) presents the results with the simplest specification with only 
infrastructure investment, and they explain about $24 \%$ of rental prices. The estimated input on the infrastructure project is significantly and negatively associated with the rental price. For each $1 \%$ increase in the infrastructure input, the rental price is decreased by $0.016 \%$.

[Insert Table 2 here]

Overall, Table 2 shows that infrastructure development on the city level decreases rental prices, while the overall infrastructure on the country level is likely to have a positive impact on rental prices.

Table 3 reports the results of how the infrastructure investment affects the cap rate. In contrast with the results on the rental market, we find a significant and positive relationship between city-level infrastructure investment and the cap rate. Column (1) reports the results of the simplest estimation with only control variables, and they explain about $16.9 \%$ of cap rate. Column (2) reports the results with control variables. For each 1\% expansion in the city's highway, the cap rate is further increased by $0.104 \%$. In Columns (3) and (4), we include the interaction term that is proxy for the total project announced at time $t$ for the given city into the regression, which is still significant and positive. Columns (5) to (8) further document the results of how the infrastructure investment affects the cap rate in the property sector. Column (5) reports the results with the simplest estimation with only infrastructure investment, and they explain about $17.9 \%$ of the cap rate. The estimated input on the infrastructure project is significantly and positively associated with the cap rate. For each $1 \%$ increase in the infrastructure input, the cap rate is increased by $0.056 \%$, a smaller magnitude compared with the penetration on the infrastructure investment. Column (6) reports the results with control variables, with a significant increase in adjusted r-squared to 49.4\%. In Columns (7) and (8), we include the interaction term in the similar vein as we did in rental price analysis.

[Insert Table 3 here]

The positive relationship between infrastructure investment and cap rate indicates an oversupply in the property sector in India. First, the Indian government has launched a massive project on housing for all by the year 2022, which has identified 305 cities and towns in nine states to begin construction of houses for the urban poor, by means of PPP and interest subsidies. Large-scale urban areas are created to attract investment and provide high-quality living standards. Urbanisation in developing countries is gradually associated 
with oversupply of the property sector. Second, it is a common view that urbanisation implies migrants leaving their rural homes to go to urban areas to work and live, or 'relocating migrants'. However, urbanisation also includes reclassification in developing countries, such as India and China. ${ }^{6}$ If a rural area is reclassified as urban, residents living in the area becomes urban residents. They are migrants by reclassification, or 'redefined migrants'. The misclassification may also contribute to the oversupply in the housing market. Third, the Indian government over-regulates the land and real estate market, possibly leading to information inefficiency on the property sector. Fiscal competition among regional governments leads to an inefficient outcome, especially with the overprovision of public infrastructure expenditure (Fuest, 1995). The possibility of the spillover effect and spatial externalities from such regional investment further complicate the dynamics of competition.

Overall, Table 3 shows that infrastructure development on the city level increases the cap rate, while the overall infrastructure at the country level does not appear to exert a positive impact on the property sector. Next, we test for robustness.

\subsection{Long-term impact of infrastructure investment}

Since we know that the benefits of infrastructure spending are not exclusive to rental prices, which tend to be relatively short term, it is important to examine whether infrastructure spending has a subsequent impact on the property market. We regress both rental price and cap rate in the subsequent periods after the infrastructure project has been announced, the results of which are reported in Table 4. The impact of access to infrastructure is amplified with a larger magnitude over time on rental prices, though a negative relationship is still evident in the short term; however, it reverts to positive after two years. As rental is a payment for property occupation and associated services, there may exist a trade-off between pollution and inconvenience from construction works and commuting benefits that may accrue after the infrastructure project is completed. Moreover, there might also be a lack of ready market take-up along with an initial higher rate of vacancy. Both of these aspects can lead to less favourable effects from infrastructure investment. Over the longer term, both of these adverse influences may dissipate, with the positive effects becoming

\footnotetext{
${ }^{6}$ The National Bureau of Statistics publishes classification codes for each of the 700,000 neighbourhoods in China from 2009 to 2013. During this period, 3.8\% of neighbourhoods were reclassified as urban neighbourhoods.
} 
more prominent and significant. As for the cap rate, the impact of access to infrastructure is positive, with increases in the cap rate over the long run. The better access to infrastructure tends to increase the supply relative to demand in the property sector, resulting in higher market cap rates over the long run.

[Insert Table 4 here]

\subsection{Alternative models}

As robustness checks, we analyse the impact of infrastructure attributes on the rental price using the vector autoregressive model for each region ${ }^{7}$ and estimate the impulse response function of different asset attributes to the rental prices. We further employ a differencein-differences approach, using the post-crisis period as a quasi-experiment, with an indicator for the global financial crisis period and its interaction with the infrastructure variables, to identify infrastructure effect versus crisis effect. The robustness tests generate similar results to those reported, which are available upon request.

\section{Policy Implications and Concluding Remarks}

The increased level of labour mobility, along with a rapid urbanisation process, raises the demand for urban amenities, contributing to land rent differentials across cities. Such effects can be especially pronounced in the context of developing countries. As the infrastructure investment is of considerable relevance to improving urban amenities, it is also likely to explain the current land rent differentials and real estate price dynamics in the property sector. In this paper, the empirical evidence shows significant evidence of the infrastructure spending on the property sector. The study finds that an increase in the percentage of public infrastructure spending has a positive effect on the cap rate in India, but it leads to a negative impact on the rental market. The robustness tests clearly indicate that there exists short-run and long-run effects. This could be due to inherent construction inconvenience and initial low take-up, which are likely to dissipate over the longer term.

\footnotetext{
${ }^{7}$ We also use the spatial lag matrix to capture the spatially weighted externality from the subject city and other cities.
} 
Overall, we document that better access to infrastructure tends to increase the supply for real estate relative to demand in the property sector, resulting in a higher market cap rate over the long run. This is especially true in the Indian context, where the infrastructure endowment is relatively low in many urban areas.

Our results have significant policy implications, in terms of forms of government interventions, strategic urban planning, issues and mechanisms of land value capture, the formation of an agglomeration economy and the nature of urbanisation.

From the government perspective, local areas should be strategically chosen that can promote uniform economic development across regions by unlocking and connecting land for economic activities. The potential positive and negative effects coming from the concentration of economic activities (i.e. the agglomeration effect) induced by the introduction of new infrastructure needs to be weighed and addressed with adequate policies that maximise the former, while keeping the latter under control. While the positive impact on the property values is beneficial from the investors' perspectives, with a likelihood of further increases in premium and density driven by the demand elasticity near new infrastructures, such effects can lead to worsening of affordability. Therefore, policies should be devised to target locations of high appreciation and provide affordable housing for low income groups and commercial space for local businesses. Also, developments closer to key infrastructure points should be required to provide amenities that promote easier access to surrounding areas. This may act as an indirect mechanism for effective land value capture. The increased revenues from the land value capture (due to price premium) can also be utilised for financing current and future infrastructure developments. The increased property tax revenue can be used for supporting social infrastructure needs of the communities, such as public education and a healthcare system. With rising urban populations, the strains on the public education and healthcare systems can be very sizeable, especially in the Indian context. Therefore, channelling the revenues from a higher base for property tax towards social infrastructure can address the typical financing challenges for these two important components of human development.

Moreover, promoting and incentivising public transport, through monetary as well as nonmonetary incentive mechanisms, will further boost the impacts on commuting costsavings and environmental benefits with lower carbon emissions. This can also reduce dependency on private transport, thus accelerating labour mobility across the regions and shaping the regional industrial ecosystem and meeting climate change goals. The 
employment problem of the affected regions can be effectively addressed. In developing countries with usually higher levels of income inequality, an efficient public transport network can alleviate and potentially eliminate the rich-poor gaps.

The co-ordinated development across large cities and their peripheral areas via an infrastructure boost helps to gather entrepreneurial innovation through agglomeration benefits, optimise supply-chain mechanisms for local businesses and accelerate regional economic upgrading. For a long time, infrastructure investment in the developing countries relied solely on government fiscal allocation or land finance. By expanding the financing channels and effectively using social capital, the PPP model can alleviate project risks as well as reduce a government's financial pressure. In this regard, connecting different regions can help mega cities to achieve functional transfer and serve as growth engines for regional economic development. For the long term, an integration of industrial and land use policies is needed to ensure continuous capital investment from both government and social capital. 


\section{References}

Ahlfeldt, G. (2011). The train has left the station: Do markets value intracity access to intercity rail connections? German Economic Review, 12 (3), 312-35.

Aschauer, D. (1989). Is public expenditure productive? Journal of Monetary Economics, 23, 177-200.

Atack, J., Bateman, F., Haines, M. and Margo, R. (2010). Did railroads induce or follow economic growth? Urbanization and population growth in the American midwest, 18501860. Social Science History, 34 (2), 171-97.

Ball, M. and Nanda, A. (2014). Does infrastructure investment stimulate building supply? Case of the English regions. Regional Studies, 48 (3), 425-38.

Banerjee, A., Duflo, E. and Qian, N. (2012). On the road: Access to transportation infrastructure and economic growth in china. NBER Working Paper No. 17897.

Baum-Snow, N. (2007). Did highways cause suburbanization? The Quarterly Journal of Economics, 122 (2), 775-805.

Baum-Snow, N., Brandt, L., Henderson, J. V., Turner, M. A. and Zhang, Q. (2012). Roads, railroads and decentralization of Chinese cities. Review of Economics \& Statistics, 99 (3), 43548.

Berndt, E. and Hansson, B. (1992). Measuring the Contribution of Public Infrastructure Capital in Sweden. The Scandinavian Journal of Economics, 94, 151-68.

Boarnet, M. G. Infrastructure services and the productivity of public capital: the case of streets and highways. National Tax Journal, 1997: 39-57.

Canning, D. and Fay, M. (1993). The Effect of Transportation Networks on Economic Growth. Columbia University, mimeo, May.

Chervachidze, S. and Wheaton,W. (2013). What determined the great cap rate compression of 2000-2007, and the dramatic reversal during the 2008-2009 financial crisis? The Journal of Real Estate Finance and Economics, 46, (2) 208-31.

Chichernea, D., Miller, N., Fisher, J., Sklarz, M. and White, R. (2008). A cross-sectional analysis of cap rates by MSA. Journal of Real Estate Research, 30 (3), 10-29.

Cohen, J. P. and Brown, M. (2017) Does a new rail rapid transit line announcement affect various commercial property prices differently? Regional Science and Urban Economics, 66, 7490.

Cohen, J. P., and Morrison Paul, C. (2004) Public infrastructure investment, interstate spatial spillovers, and manufacturing costs. Review of Economics and Statistics, 86, (2) 551-60.

Cohen, J. P. and Morrison Paul, C. (2007). The impacts of transportation infrastructure on property values: A higher-order spatial econometrics approach. Journal of Regional Science, 47 (3), 457-78.

Datta, S. (2012). The impact of improved highways on Indian firms. Journal of Development Economics, 99 (1), 46-57. 
Duffy-Deno, K. and Eberts, R. (1991). Public infrastructure and regional economic development: A simultaneous equations approach. Journal of Urban Economics, 30, 329-43.

Evans, P. and Karras, G. (1993). Is government capital productive? Evidence from a panel of seven countries. Journal of Macroeconomics, 16 (2), 271-79.

Faber, B. (2014). Trade integration, market size, and industrialization: Evidence from China's national trunk highway system. The Review of Economic Studies, 2014.

Fuest, C (1995). Interjurisdiction competition and public expenditure: Is tax co-ordination counterproductive? FinanzArchiv, 52, 478-96.

Garcia-Milà, T. and McGuire, T. (1992). The contribution of publicly provided inputs to states' economies. Regional Science and Urban Economics, 22, 229-41.

Garcia-Milà, T., McGuire, T. and Porter, R. (1996). The effect of public capital in statelevel productions functions reconsidered. Review of Economics and Statistics, 78 (1), 177-80.

Ghani, E., Goswami, A. and Kerr, W. (2012). Highway to success: The impact of the golden quadrilateral project for the location and performance of Indian manufacturing. Technical report. NBER Working Paper No. 18524.

Gibbons, S. and Machin, S. (2008). Valuing school quality, better transport and lower crime: Evidence from house prices. Oxford Review of Economic Policy, 4 (1), 99-119.

Gramlich, E. (1994). Infrastructure investment: A review essay. Journal of Economic Literature, 32, 1176-96.

Guerrieri, V., Hartley, D. and Hurst, E. (2010). Endogenous gentrification and housing price dynamics, NBER Working Paper No. 16237

Haughwout, F, (1997). Central city infrastructure investment and suburban house values, Regional Science and Urban Economics, 27, 199-215.

Haughwout, F, (1998). Aggregate production functions, interregional equilibrium, and the measurement of infrastructure productivity. Journal of Urban Economics, 44, 216-27.

Holtz-Eakin, D. (1994). Public sector capital and the productivity puzzle. The Review of Economics and Statistics, 76 (1), 12-21.

Holtz-Eakin, D. and Schwartz, A. E. (1995). Spatial productivity spillovers from public infrastructure: Evidence from state highways. International Tax and Public Finance, 2 (3), 459_ 68.

Kahn, M. (2007). Gentrification trends in new transit-oriented communities: Evidence from 14 cities that expanded and built rail transit systems. Real Estate Economics, 35 (2), 155 82.

Kahn, M., Vaughn, R. and Zasloff, J. (2010). The housing market effects of discrete land use regulations: Evidence from the California coastal boundary zone. Journal of Housing Economics, 19 (4), 269-79.

Kelejian, H. H. and Robinson, D. P. (1997). Infrastructure productivity estimation and its underlying econometric specifications: A sensitivity analysis. Papers in Regional Science, 76 (1), 115-31. 
Lynde, C. and Richmond, J. (1991). The role of public capital in production. The Review of Economics and Statistics, LXXIV (1), 37-44.

McDonald, J. and McMillen, D. (2010). Urban Economics and Real Estate: Theory and Policy. Wiley Desktop Editions.

Morrison, C. J., and Schwartz, A. E. (1996). Public infrastructure, private input demand, and economic performance in New England manufacturing. Journal of Business \& Economic Statistics, 14, (1), 91-101.

Munnell, A. (1992). Infrastructure, investment and economic growth. Journal of Economic Perspectives, 6, 189-98.

Munnell, A. and Cook, L. (1990). How does public infrastructure affect regional economic performance? New England Economic Review, September/October, Federal Reserve Bank of Boston, 11-33.

Nadiri, M. and Mamuneas, T. (1994). The effects of public infrastructure and R\&D capital on the cost structure and performance of US manufacturing industries. The Review of Economics and Statistics, 76 (1), 22-37.

Nanda, A. and Tiwari, P. (2013).Sectoral and spatial spillover effects of infrastructure investment: A case study of Bengaluru, India. The Royal Institution of Chartered Surveyors (RICS) Research Report. July 2013.

Nanda, A. (2012). The big infrastructure need in India should be prioritized. Realism.IN, October 29, 2012.

Newell, G. and Peng, H. (2008). The role of US infrastructure in investment portfolios. Journal of Real Estate Portfolio Management, 14 (1), 21-32.

OECD (2008). Infrastructure to 2030 OECD Policy Brief. Technical Report.

Pereira, A. and Andraz, J. (2004). Public highway spending and state spillovers in the US. Applied Economics Letters, 11, 785-88.

Pereira, A. and Andraz, J. (2006). Public investment in transportation infrastructures and regional asymmetries in Portugal. The Annals of Regional Science, 40 (4), 803-17.

Pereira, A. and Andraz, J. (2008). On the regional incidence of public investment in highways in the USA. College of William and Mary Working Paper No. 70.

Pereira, A. and Roca-Sagales, O. (2002). Spillover effects of public capital formation: Evidence of Spanish regions. Journal of Urban Economics, 53, 238-56.

Prud'homme, R. (2005). Infrastructure and development,. In: B. Francois and B. Pleskovic. (eds) Lessons of Experience. Washington, DC: The World Bank and Oxford University Press, pp. 153-81.

Seitz, H. (1994). Public capital and the demand for private inputs. Journal of Public Economics, 54, 287-307.

Seitz, H. and Licht, G. (1995). The impact of public infrastructure capital on regional manufacturing production cost. Regional Studies, 29, 231-40. 
Shah, A. (1992). Dynamics of public infrastructure, industrial productivity and profitability. The Review of Economics and Statistics, LXXIV (1), 28-36.

Shirley, C. and Winston, C. (2004). Firm inventory behavior and returns to highway infrastructure investment. Journal of Urban Economics, 55, 398-415.

Tatom, J. (1991). Public capital and private-sector performance. Review of the Federal Reserve Bank of St. Louis, 78 (3), 3-15.

UN (2008). United Nations Expert Group Meeting on Population Distribution, Urbanization, Internal Migration and Development, Population Division, New York, 2123 January. 2008. 


\section{Table 1: Descriptive Statistics}

This table describes the key variables used in the empirical analysis.

Variable Name
Panel A: Variables of Interests
Rental
CapRate (\%)
Panel B: Infrastructure Spending

Infras_dummy

Infras_length

Infras_lengthtotal

Infras_spending (in billion)

Infras_spendingtotal (in billion)

\section{Panel C: Control Variables}

Risk Premium (\%)

Rental Change

Area (sqft)

GDP

Consumption

CPI

Stock

M2
The rental price recorded on the lease transaction Transaction data $j$ of city $i$ at time $t$ (per sqft)

The rental price recorded on the lease transaction $j$ of city $i$ over the selling price of a comparable Transaction data property at time $t$

Data Sources

Mean

Std

Min

$\operatorname{Max}$

$64.99 \quad 51.56 \quad 12$

$\begin{array}{lll}6.85 & 24.51 \quad 0.76\end{array}$

Equals to 1, if the infrastructure investment is

observed for the given city at time $t$

Hand-collected data

$0.202 \quad 0.402$

0

1

Hand-collected data

$57.85 \quad 164.6 \quad 0$

1292

The length of highway projects under
construction for the given city at time $t(\mathrm{~km})$

Hand-collected data

$16785.99 \quad 4427.01 \quad 5959.25$

19711.67

construction or completed by time $t(\mathrm{~km})$

The estimated spending on the infrastructure

investment under constructed for the given city at Hand-collected data time $t$ (INR. crore)

$193.39 \quad 732.60$

30000

The total estimated spending on the infrastructure investment under construction or completed for Hand-collected data the given city at time $t$ (INR. crore)

The market factor, the difference of stock market return over risk free rate

DataStream

$3.27 \quad 1.95$

2.24

6.95

The deviation from the long-run average rental price for each city

Transaction data

$0.02 \quad 0.54 \quad-1.51$

2.19

The size of property on file

Transaction data

430.

648.9

1.85

8000

The log difference of gross domestic product (GDP)

DataStream

9.51

0.12

8.92

9.75

The log difference of private consumption

DataStream

8.98

0.13

8.41

9.19

The log difference of CPI

DataStream

5.24

0.16

4.69

5.48

The log difference of the stock index

DataStream

8.56

0.17

7.36

8.75

The log difference of M2

DataStream 
Table 2: The Impact of Infrastructure Investment on Rental Prices, 2008-2014

This table presents the relationship between the infrastructure attributes and rental prices. The dependent variable is $\ln ($ Rental Price). All variables are as defined in Table $1 . *$, ** and *** represent the $10 \%, 5 \%$ and $1 \%$ significance levels, respectively. Coefficients for the variables of interest are presented in sequence, and robust standard errors are included in parentheses.

\begin{tabular}{|c|c|c|c|c|c|c|c|c|}
\hline \multicolumn{9}{|c|}{ In(Rental Price) } \\
\hline & Column 1 & Column 2 & Column 3 & Column 4 & Column 5 & Column 6 & Column 7 & Column 8 \\
\hline \multirow[t]{2}{*}{ In(Infras_length) } & $-0.023 * * *$ & $-0.024 * * *$ & & & & & & \\
\hline & $(0.005)$ & $(0.005)$ & & & & & & \\
\hline \multicolumn{9}{|l|}{ Infras_dummy * } \\
\hline \multirow[t]{2}{*}{ In(Infras_lengthtotal) } & & & $-0.012 * * *$ & $-0.012 * * *$ & & & & \\
\hline & & & $(0.003)$ & $(0.003)$ & & & & \\
\hline \multirow[t]{2}{*}{ In(Infras_lengthtotal) } & -0.031 & -0.010 & -0.038 & -0.032 & & & & \\
\hline & $(0.029)$ & $(0.055)$ & $(0.029)$ & $(0.054)$ & & & & \\
\hline \multirow[t]{2}{*}{ In(Infras_spending) } & & & & & $-0.016^{* * *}$ & $-0.016^{* * *}$ & & \\
\hline & & & & & $(0.004)$ & $(0.004)$ & & \\
\hline \multicolumn{9}{|l|}{ Infras_dummy* } \\
\hline \multirow[t]{2}{*}{ In(Infras_spendingtotal) } & & & & & & & $-0.010 * * *$ & $-0.010 * * *$ \\
\hline & & & & & & & $(0.002)$ & $(0.002)$ \\
\hline \multirow[t]{2}{*}{ In(Infras_spendingtotal) } & & & & & -0.055 & -0.038 & -0.067 & -0.049 \\
\hline & & & & & $(0.053)$ & $(0.101)$ & $(0.053)$ & $(0.100)$ \\
\hline \multirow[t]{2}{*}{$\ln$ (Area) } & & $-0.085 * * *$ & & $-0.085 * * *$ & & $-0.085 * * *$ & & $-0.085 * * *$ \\
\hline & & $(0.009)$ & & $(0.009)$ & & $(0.009)$ & & $(0.009)$ \\
\hline \multirow[t]{2}{*}{$G D P$} & & $-0.392 *$ & & $-0.412 * *$ & & $-0.384 *$ & & $-0.413 * *$ \\
\hline & & $(0.208)$ & & $(0.209)$ & & $(0.208)$ & & $(0.209)$ \\
\hline \multirow[t]{2}{*}{ Consumption } & & 0.014 & & 0.068 & & 0.026 & & 0.065 \\
\hline & & $(0.273)$ & & $(0.274)$ & & $(0.273)$ & & $(0.274)$ \\
\hline \multirow[t]{2}{*}{$C P I$} & & 0.107 & & 0.122 & & 0.129 & & 0.104 \\
\hline & & $(0.466)$ & & $(0.467)$ & & $(0.464)$ & & $(0.464)$ \\
\hline \multirow[t]{2}{*}{ Stock } & & $-0.238 * * *$ & & $-0.228 * *$ & & $-0.239 * * *$ & & $-0.234 * * *$ \\
\hline & & $(0.089)$ & & $(0.089)$ & & $(0.089)$ & & $(0.089)$ \\
\hline \multirow[t]{2}{*}{$M 2$} & & 0.000 & & 0.000 & & 0.000 & & 0.000 \\
\hline & & $(0.000)$ & & $(0.000)$ & & $(0.000)$ & & $(0.000)$ \\
\hline Micromarket Fixed Effect & Yes & Yes & Yes & Yes & Yes & Yes & Yes & Yes \\
\hline State Fixed Effect & Yes & Yes & Yes & Yes & Yes & Yes & Yes & Yes \\
\hline Constant & Yes & Yes & Yes & Yes & Yes & Yes & Yes & Yes \\
\hline No. of Obs. & 2,675 & 2,675 & 2,675 & 2,675 & 2675 & 2,675 & 2,675 & 2,675 \\
\hline Adjusted $\mathrm{R}^{2}$ & 0.242 & 0.265 & 0.240 & 0.263 & 0.240 & 0.263 & 0.240 & 0.263 \\
\hline
\end{tabular}




\section{Table 3: The Impact of Infrastructure Investment on Cap Rate, 2008-2014}

This table presents the relationship between the infrastructure attributes and the cap rate. The dependent variable is $\ln ($ Cap Rate). All variables are as defined in Table 1. *,** and *** represent the $10 \%, 5 \%$ and $1 \%$ significance levels, respectively. Coefficients for the variables of interest are presented in sequence, and robust standard errors are included in parentheses.




Table 4: The Long-term Impact of Infrastructure Investment

This table presents the relationship between the infrastructure attributes and the property market. All variables are as defined in Table 1. *,** and *** represent the $10 \%, 5 \%$ and $1 \%$ significance levels, respectively. Coefficients for the variables of interest are presented in sequence, and robust standard errors are included in parentheses.

\begin{tabular}{|c|c|c|c|c|c|c|c|c|}
\hline & \multicolumn{4}{|c|}{ In(Rental price) } & \multicolumn{4}{|c|}{$\ln ($ Cap rate $)$} \\
\hline & \multicolumn{2}{|c|}{ After one year } & \multicolumn{2}{|c|}{ After two years } & \multicolumn{2}{|c|}{ Cap rate after one year } & \multicolumn{2}{|c|}{ Cap rate after two years } \\
\hline & Column1 & Column 2 & Column 3 & Column 4 & Column 5 & Column 6 & Column 7 & Column 8 \\
\hline \multirow[t]{2}{*}{ In(Infras_length) } & $0.008^{*}$ & & $0.016^{* * *}$ & & $0.094 * * *$ & & $0.114 * * *$ & \\
\hline & $(0.005)$ & & $(0.005)$ & & $(0.021)$ & & $(0.031)$ & \\
\hline \multirow[t]{2}{*}{ In(Infras_lengthtotal) } & -0.057 & & $-0.181 * * *$ & & -0.060 & & $0.389 * * *$ & \\
\hline & $(0.054)$ & & $(0.067)$ & & $(0.287)$ & & $(0.139)$ & \\
\hline \multirow[t]{2}{*}{ In(Infras_Spending) } & & $0.009^{* *}$ & & $0.010^{* * *}$ & & $0.074 * * *$ & & $0.088^{* * *}$ \\
\hline & & $(0.004)$ & & $(0.004)$ & & $(0.018)$ & & $(0.028)$ \\
\hline \multirow[t]{2}{*}{ In(Infras_Spendingtotal) } & & $-0.109^{* * *}$ & & $-0.082 * *$ & & 0.137 & & $0.794 * * *$ \\
\hline & & $(0.040)$ & & $(0.033)$ & & $(0.524)$ & & $(0.290)$ \\
\hline \multirow[t]{2}{*}{ Risk Premium } & & & & & $-0.358 * * *$ & $-0.348 * * *$ & $-0.252 * * *$ & $-0.228 * * *$ \\
\hline & & & & & $(0.045)$ & $(0.042)$ & $(0.047)$ & $(0.047)$ \\
\hline \multirow[t]{2}{*}{ Rentalchange } & & & & & $1.018^{* * *}$ & $1.008^{* * *}$ & $0.700^{* * *}$ & $0.712 * * *$ \\
\hline & & & & & $(0.065)$ & $(0.065)$ & $(0.064)$ & $(0.064)$ \\
\hline \multirow[t]{2}{*}{$\ln ($ Area $)$} & $-0.086^{* * *}$ & $-0.086^{* * *}$ & $-0.085^{* * *}$ & $-0.085^{* * *}$ & $-1.102 * * *$ & $-1.101 * * *$ & $-0.932 * * *$ & $-0.946 * * *$ \\
\hline & $(0.009)$ & $(0.009)$ & $(0.009)$ & $(0.009)$ & $(0.046)$ & $(0.046)$ & $(0.052)$ & $(0.051)$ \\
\hline \multirow[t]{2}{*}{$G D P$} & -0.123 & -0.160 & $-0.413^{*}$ & $-0.432 * *$ & $10.146^{* * *}$ & $10.077^{* * *}$ & $12.259 * * *$ & $12.442 * * *$ \\
\hline & $(0.208)$ & $(0.207)$ & $(0.212)$ & $(0.210)$ & $(0.924)$ & $(0.918)$ & $(0.908)$ & $(0.964)$ \\
\hline \multirow[t]{2}{*}{ Consumption } & $-0.708^{* *}$ & $-0.610^{* *}$ & $-0.576^{* *}$ & $-0.478^{*}$ & $-4.592 * * *$ & $-4.542 * * *$ & 1.009 & -0.737 \\
\hline & $(0.278)$ & $(0.278)$ & $(0.281)$ & $(0.284)$ & $(1.246)$ & (1.247) & (1.408) & (1.359) \\
\hline \multirow[t]{2}{*}{$C P I$} & 0.157 & 0.052 & $1.936^{* * *}$ & $1.471 * * *$ & $-5.473 * *$ & $-6.687 * * *$ & 2.529 & $-3.408 *$ \\
\hline & $(0.518)$ & $(0.518)$ & $(0.531)$ & $(0.530)$ & $(2.130)$ & (2.179) & $(1.796)$ & (1.920) \\
\hline \multirow[t]{2}{*}{ Stock } & $0.231 * * *$ & $0.215^{* * *}$ & -0.035 & -0.059 & 0.293 & 0.226 & $1.496 * * *$ & $1.106^{* * *}$ \\
\hline & $(0.056)$ & $(0.056)$ & $(0.047)$ & $(0.049)$ & $(0.313)$ & $(0.307)$ & $(0.223)$ & $(0.216)$ \\
\hline \multirow[t]{2}{*}{$M 2$} & 0.000 & 0.000 & -0.000 & -0.000 & 0.000 & 0.000 & $0.001 * * *$ & $0.001 * * *$ \\
\hline & $(0.000)$ & $(0.000)$ & $(0.000)$ & $(0.000)$ & $(0.000)$ & $(0.000)$ & $(0.000)$ & $(0.000)$ \\
\hline Micro market Fixed Effect & Yes & Yes & Yes & Yes & Yes & Yes & Yes & Yes \\
\hline State Fixed Effect & Yes & Yes & Yes & Yes & Yes & Yes & Yes & Yes \\
\hline Constant & Yes & Yes & Yes & Yes & Yes & Yes & Yes & Yes \\
\hline No. of Obs. & 2,675 & 2,675 & 2,675 & 2,675 & 1,076 & 1,076 & 895 & 895 \\
\hline Adjusted $\mathrm{R}^{2}$ & 0.265 & 0.266 & 0.266 & 0.265 & 0.544 & 0.543 & 0.618 & 0.597 \\
\hline
\end{tabular}


Figure 1: Debate on Infrastructure and Economic Growth

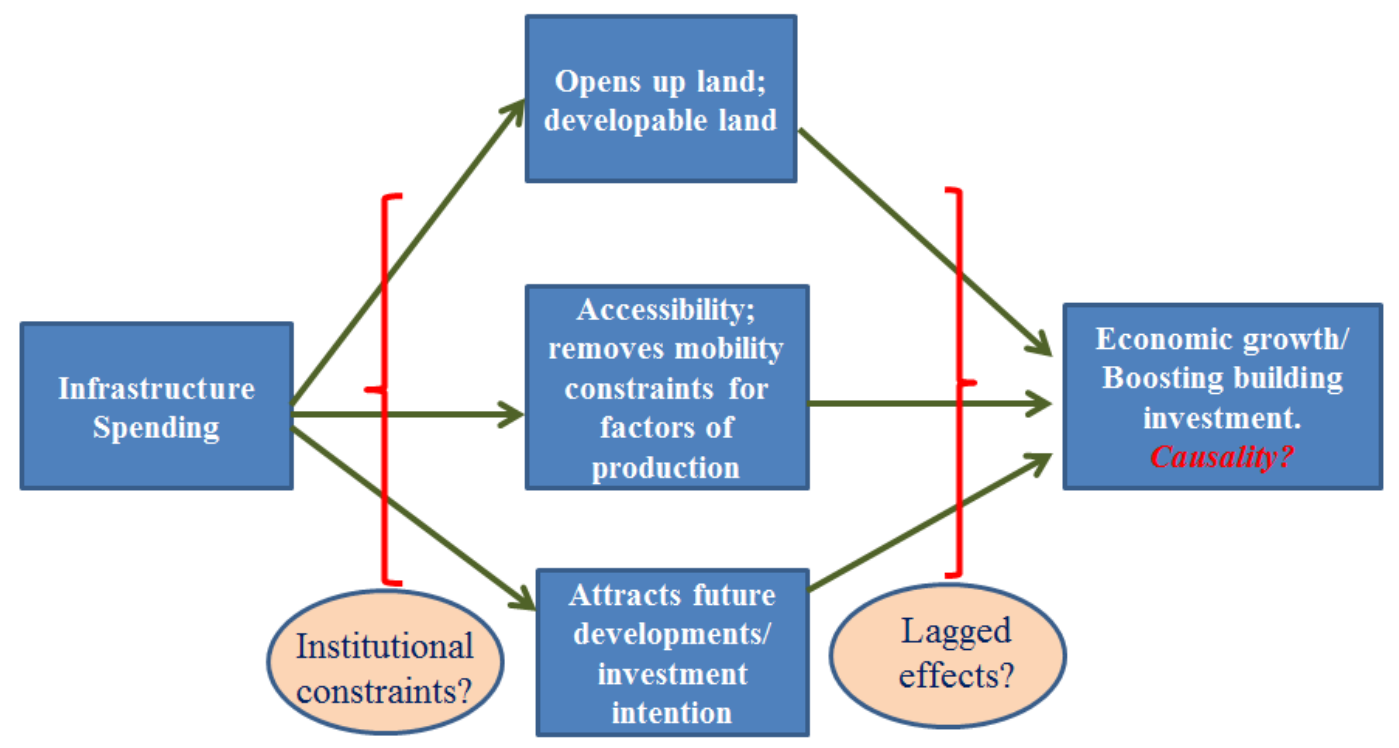

Source: Nanda (2012) 